\title{
Activation of Wnt signalling in acute myeloid leukemia by induction of Frizzled-4
}

\author{
LARA TICKENBROCK $^{1}$, SINA HEHN ${ }^{1}$, BÜLENT SARGIN ${ }^{1}$, CHUNARAM CHOUDHARY $^{1}$, \\ NICOLE BÄUMER ${ }^{1}$, HORST BUERGER $^{2,4}$, BERND SCHULTE $^{2}$, OLIVER MÜLLER ${ }^{5}$, \\ WOLFGANG E. BERDEL ${ }^{1}$, CARSTEN MÜLLER-TIDOW ${ }^{1}$ and HUBERT SERVE ${ }^{3}$
}

\author{
${ }^{1}$ Department of Medicine, Hematology and Oncology, ${ }^{2}$ Gerhard Domagk Institute of Pathology, University of \\ Muenster, Muenster; ${ }^{3}$ Medizinische Klinik II, Klinikum der Johann-Wolfgang Goethe-Universitaet Frankfurt am \\ Main; ${ }^{4}$ Institut für Pathologie, Paderborn; ${ }^{5}$ Max-Planck-Institut für Molekulare Physiologie, Dortmund, Germany
}

Received May 15, 2008; Accepted July 22, 2008

$$
\text { DOI: 10.3892/ijo_00000111 }
$$

\begin{abstract}
Wnt signalling regulates proliferation, self renewal and cell fate. Aberrant Wnt signalling is thought to contribute to AML pathogenesis by enhancing self renewal. Herein, we provide evidence for increased expression of Frizzled-4, a receptor for Wnt ligands, in primary AML blasts compared to normal bone marrow on the protein level. In addition, Frizzled-4 is highly expressed in human CD34 positive cells as well as in lineage negative sorted mouse bone marrow cells. Functionally, Frizzled-4 expression modulates apoptosis and enhances Wnt3a induced $\beta$-catenin stability in myeloid progenitor cells. Frizzled-4-dependent $\beta$-catenin stabilization is dkk-1 sensitive, implicating a specific Wnt-ligand/Frizzledreceptor interaction. These findings indicate enhanced sensitivity of AML blasts for Wnt-ligands and suggest an additional mechanism of Wnt signalling activation in the pathogenesis of AML.
\end{abstract}

\section{Introduction}

The Wnt signalling pathway regulates embryonic development in a context-dependent manner through changes in proliferation, cell fate and movement (1). Also, Wnt signalling has been implicated in the development of a variety of human cancers (2). Wnts activate a wide range of biological effects through binding to Frizzled receptors (Fzd), members of the seven-transmembrane receptor family and the single-span low density lipoprotein receptor-related protein (LRP) $(3,4)$. Wnt binding triggers the release of $\beta$-catenin from a destruction complex, containing Axin, the adenomatous polyposis coli gene product (APC), glycogen synthase kinase 33 (GSK3ß)

Correspondence to: Dr Lara Tickenbrock, Department of Medicine, Hematology and Oncology, University of Muenster, Domagkstr. 3, 48149 Muenster, Germany

E-mail: tickenbr@uni-muenster.de

Key words: AML, Wnt, ß-catenin, Frizzled-4, Flt3 and other proteins, which in the absence of Wnts promote ubiquitin-mediated degradation of $ß$-catenin (1). Subsequently, free $\beta$-catenin shuttles into the nucleus and acts as a transcriptional coactivator of TCF/LEF-family members to induce Wnt-target genes (5). Its biological significance in hematopoiesis and stem cell self renewal has been described previously (6). However, results obtained by individual gene ablations of the two known signal transmitters $\beta$ - and $\gamma$ catenin have thus far failed to support a critical role of this pathway in normal hematopoiesis whereas in vivo gain of function experiments clearly demonstrate effects on B-catenin on proliferation and differentiation potential of hematopoietic cells (7-9). Loss-of-function mutations in Frizzled-4 (Fz4) and the co-receptor LRP5, have been demonstrated in familial exsudative vitreoretinopathy (FEVR) $(10,11)$. Robitaille and colleagues reported a function for Frizzled-4 in retinal angiogenesis and established the first association between a Wnt-receptor and a human disease (11); a mutant allele of Fz4, encoding a truncated protein that is retained in the endoplasmic reticulum, is linked to the autosomal-dominant retinal degenerative disease, ramilial exudative vitreoretinopathy (FEVR). Furthermore, this mutant form of Fz4 oligomerizes with wild-type Fz4, retains it in the endoplasmic reticulum and inhibits its signalling (12). Xu et al showed that Norrin, the protein product of the Norrie disease gene, that is a secreted protein of unknown function, acts as ligand for the Fz4 receptor and induces activation of the classical Wnt pathway (10). Finally, the detailed expression pattern analyses of different Wnts components in the murine small intestine and colon and adenomas established distinct expression patterns of Fzd4 in normal versus neoplastic tissue (13).

Despite the known involvement in Wnt signalling, relatively little is known about the role of Frizzleds in the hematopoietic system. Previously, we identified a role for canonical Wnt signalling in translocation product induced pathogenesis of AML as well as in Flt3-ITD-mediated leukemic transformation $(14,15)$. Higher mRNA levels of Frizzled-4 were observed in Flt3-ITD transformed murine progenitor $32 \mathrm{D}$ cells compared to the wild-type. Overexpression of signalling receptors is an established mechanism 
A

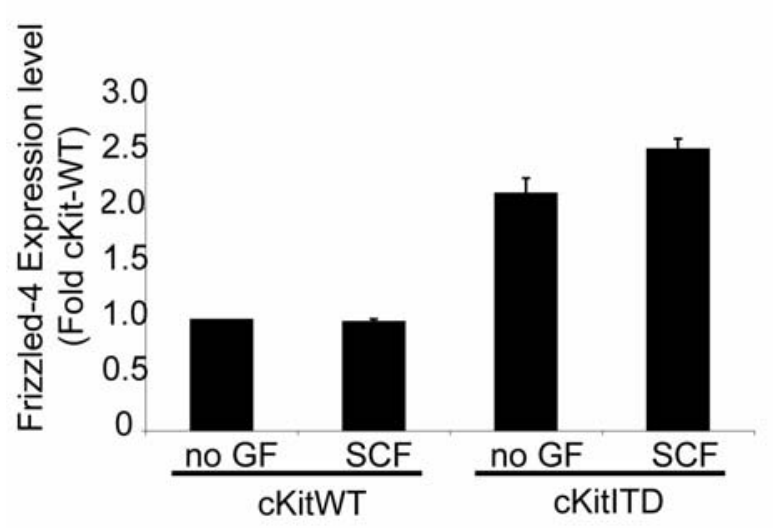

B

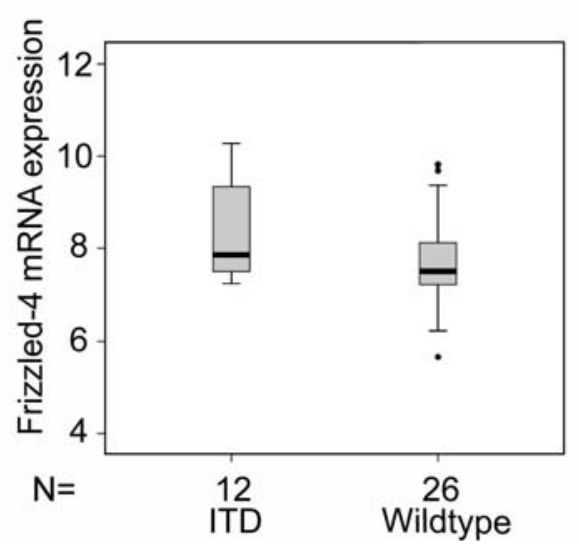

Figure 1. Frizzled-4 mRNA expression in cKit overexpressing cells and primary AML samples. (A) Bar diagrams show the relative Frizzled-4 mRNA expression in stably transfected 32DcKit-ITD cells compared to 32DcKit-WT. Cells were starved overnight and then cultured either with no growth factor or SCF (10 ng/nl) for $6 \mathrm{~h}$. Retroviral transduction and real-time RT-PCR were performed as described (14,20). (B) Box plots represent the levels of Frizzled-4 mRNA expression as analyzed by microarray analyses in a cohort of 80 patients.

in oncogenic transformation (16). This let us hypothesize that high levels of receptors for canonical Wnt ligands might act as regulatory components in leukemic transformation.

\section{Methods and methods}

Patient samples. All samples were collected from patients enrolled in a treatment optimization trial in Germany (17). Written informed consent was obtained from all individuals.

Cell lines and protein purification and apoptosis. The IL3dependent murine myeloid progenitor cell line 32Dcl3 was cultured in RPMI-1640 supplemented with $10 \%$ WEHIconditioned medium as a source of IL3 as described earlier $(18,19)$. For generating Frizzled-4 overexpressing cell lines, 32DFlt3-wild-type cells were retrovirally transduced with pMY-Frizzled-4-IRES-EGFP. The EGFP positive cells were sorted and cultured. Producing retroviral supernatants, 32DcKit constructs and apoptosis assays were performed as described (20).

Wnt3a conditioned medium was prepared from confluent cultures of Wnt3a-producing L cells (stably transfected with Wnt3a cDNA, ATCC) or control L cells (ATCC), grown in supplemented DMEM. Culture supernatants were collected after 3-4 days. Purified mouse Dkk-1, containing a His- and a Flag-tag sequence was kindly provided by Dr Cati Logan and Dr Calvin Kuo, Stanford, CA (21).

RNA-isolation, generation of cDNA and real-time RT-PCR. Total RNA was isolated using Trizol reagent (Invitrogen, Karlsruhe, Germany) according to the manufacturer's recommendations. In brief, $1 \mu \mathrm{g}$ total RNA was used for reverse transcription. The cDNA was diluted to $200 \mu \mathrm{l}$ with $\mathrm{ddH}_{2} \mathrm{O}$, and $2.5 \mu 1$ were used for each PCR reaction. The quantitation of mRNA levels was carried out using a real-time fluorescence detection method as described previously $(15,22)$. Relative gene expression levels were calculated using standard curves generated by the serial dilutions of cDNA from 32D cells. All samples were independently analyzed at least twice for each gene. The housekeeping gene GAPDH served as an additional control for the cDNA quality.

For the analysis of Frz-4 expression in different hematopoietic cells, red cell-lysed bone marrow C57/bl6N wildtype mice were incubated with the respective antibody (c-Kit, B220, GR1, CD11b, Ter119, CD41, all BD Biosciences, Franklin Lakes, NJ, USA) for $1 \mathrm{~h}$ on ice in the dark. Lineage depletion was obtained using the Lineage cell depletion kit mouse (Miltenyi Biotec, Bergisch Gladbach, Germany) according to the manufacturer's protocol. RNA from sorted bone marrow subsets was isolated using Qiagen MicroRNAsy kit (Hilden, Germany) according to the manufacturer's recommendations.

Western blot analyses and antibodies. Cell lysates and Western blotting were performed as described $(14,20)$. Frizzled-4 antibody was purchased from R\&D Systems (Wiesbaden, Germany), anti- $\beta$-catenin mouse monoclonal antibody was obtained from Transduction Laboratories (Lexington, KY, USA), and the anti-mouse actin monoclonal antibody was obtained from Sigma (Taufkirchen, Germany). Horseradish peroxidase coupled goat anti-rabbit and goat anti-mouse antibodies were purchased from Jackson Immuno Laboratories (West Grove, PA, USA).

Statistics. All data were evaluated by the Mann-Whitney U test and $\mathrm{P} \leq 0.05$ were considered significant. All error bars represent standard deviations.

Tissue array construction and immunohistochemistry analyses. Tissue array construction with primary AML, CD34+ cells of healthy donors and cell lines were performed as described previously (23).

Microarray. Microarray expression analysis was performed using the microarray analyser 1700 from ABI according to the manufacturer's protocol (24). Total RNA (2 $\mu \mathrm{g})$ were reverse-transcribed and second-strand synthesis was performed. Digoxigenin-UTP was included in the IVT-reaction to produce 
A negative

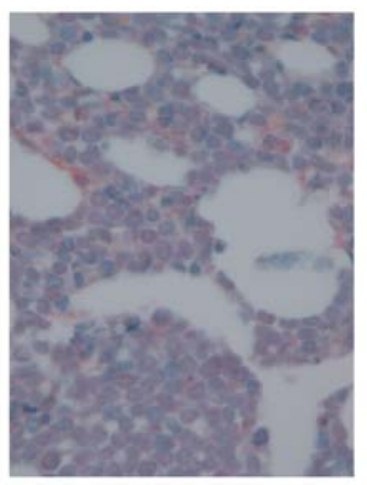

B

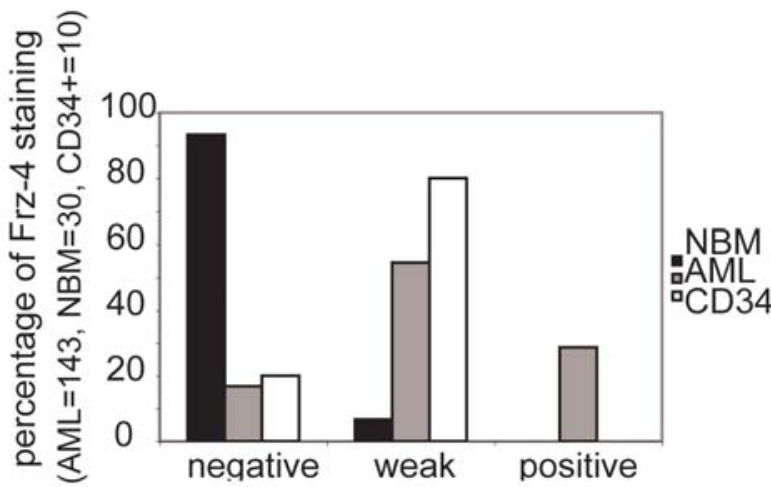

Figure 2. Frizzled-4 protein expression in primary AML samples. (A) The photos depict the immunohistochemical findings for Frizzled-4 negative or positive staining of the tissue array. (B) Percentage of Frizzled-4 staining in a tissue array compared to normal bone marrow samples (AML, N=143; normal bone marrow, $\mathrm{N}=30$; $\mathrm{CD} 34, \mathrm{~N}=10$ ).

\begin{tabular}{c|c}
\hline \hline 32D parental & + \\
\hline 32D huFLT3-WT & + \\
\hline HCT p53 +/+ & ++ \\
\hline HCT p53 -t & ++ \\
\hline HEK 293 & ++ \\
\hline Hela & ++ \\
\hline Jurkat & ++ \\
\hline K562 & ++ \\
\hline MC62 & + \\
\hline ML1 & ++ \\
\hline MV411 & ++ \\
\hline NB4 & + \\
\hline NIH3T3 & ++ \\
\hline Oci AML5 & + \\
\hline T47 D1 & ++ \\
\hline U87 + Ly & + \\
\hline U87 - Ly & + \\
\hline U937 & ++ \\
\hline \hline
\end{tabular}

Figure 3. Distribution of Frizzled-4 protein expression in CD34 positive cells and several cell lines. Different cells were immunohistochemically analyzed for Frizzled-4 protein expression (-, negative; +, positive; ++, highly positive).

DIG-labelled cRNA that after fragmentation was hybridized to the Genome survey expression arrays (ABI). Detection was performed by a chemiluminescent reaction with high sensitivity and primary analyses were performed with the 1700 chemiluminescent microarray analyser (ABI).

\section{Results}

In prior studies, we described for the first time a role for Wnt signalling in the pathogenesis of AML $(14,15)$. We found that Wnt signalling regulators were modified in their expression by the presence of Flt3-ITD in the murine hematopoietic progenitor cell line 32D. Microarray analyses revealed higher mRNA expression of Frizzled-4 in 32D/ Flt3ITD cells compared with 32D/Flt3-WT. These findings were verified by quantitative real-time reverse transcriptionpolymerase chain reaction and on the protein level.

Frizzled-4 receptor is expressed in AML patients compared to normal bone marrow. We analyzed Frizzled-4 RNA levels in stably transfected cKit-ITD expressing 32D cells. The amount of Frizzled-4 RNA was significantly higher in cKit-ITD expressing cells compared to WT transfected cells (Fig. 1A). Next, we analyzed microarray data from blasts of 38 AML patients. The data in Fig. 1B show that Frizzled-4 RNA is widely expressed in AML patients regardless of the presence or absence of Flt3 mutations. These data implicate, that different mechanisms exist besides ITD-mutations in patients that induce Frizzled-4 RNA.

To further confirm these findings bone marrow biopsies from 143 patients as well as from 30 patients with normal bone marrow, $10 \mathrm{CD} 34$ positive samples and several leukemic cell lines were prepared as tissue arrays and analyzed for Frizzled-4 protein expression (Fig. 2A and B). Fig. 2A shows examples for negative and positive staining for Frizzled-4 expression. The immunostaining indicated that blasts from $\sim 80 \%$ of all AML patients expressed Frizzled- 4 on the protein level. Frizzled-4 was rarely expressed in normal bone marrow $(2 / 30,6.7 \%)$. Frizzled-4 was also expressed in normal CD34 positive hematopoietic progenitor cells with eight of ten samples being positive for expression. This result indicates a function of Frizzled-4 receptor in the stem cell compartment as normal bone marrow samples contain low stem cell numbers and were negative for Frizzled-4 staining, whereas CD34 positive cells are enriched for progenitor cells. The immunohistochemical distribution pattern of Frizzled-4 in a variety of different cells is shown in Fig. 3. These data clearly show, that Frizzled-4 protein is widely expressed in a variety of leukemic cell lines. In line with these data are the experiments 
A

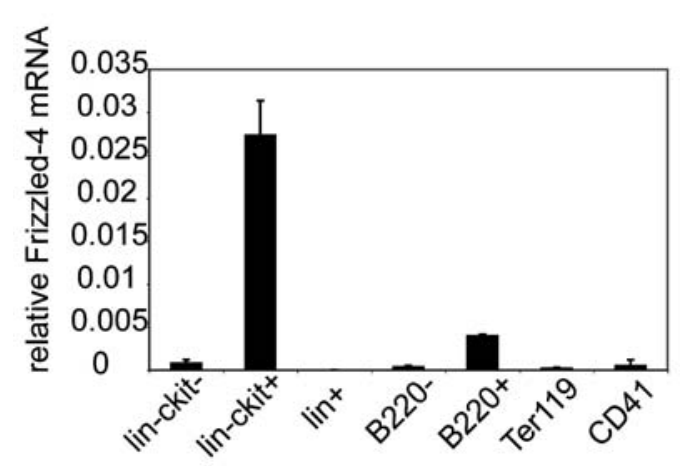

B

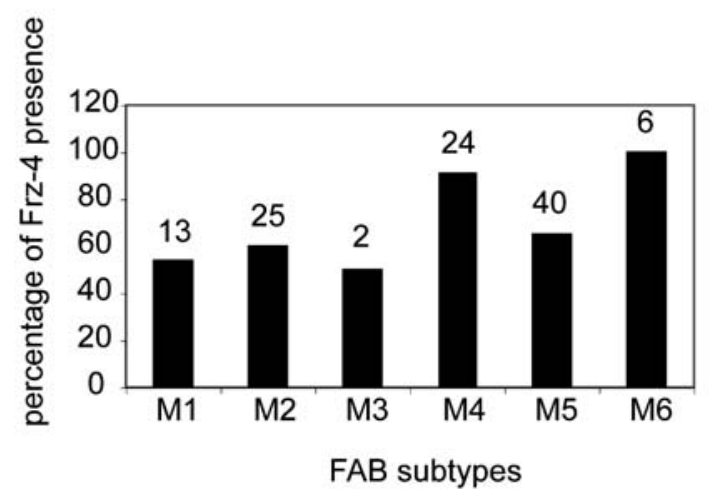

Figure 4. Frizzled-4 expression in sorted mouse bone marrow cells and distribution in FAB classes of AML-tissue arrays. (A) Taqman analyses of sorted mouse bone marrow cells. (B) Bar diagrams represent the average Frizzled-4 presence in different FAB classes. Numbers above the bars represent the total number of patients for each FAB class.

A

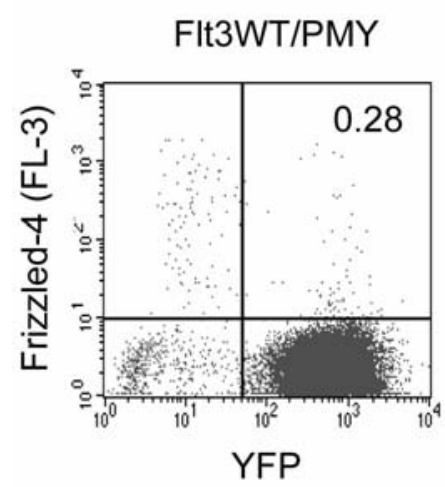

B

\section{FIt3WT/PMY-Frz.4}

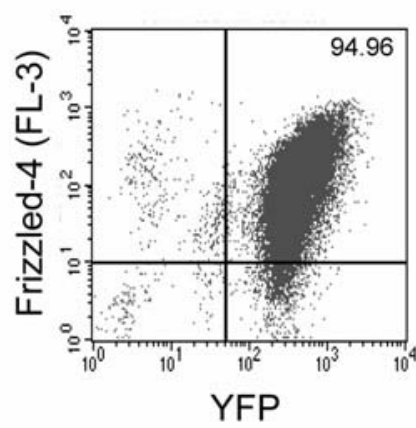

Figure 5. To establish Frizzled-4 overexpressing cell lines, 32D Flt3-wildtype cells were retrovirally transduced with pMY-Frizzled-4-IRES-EGFP (B) or empty vector (PMY, A). Frizzled-4 expression was determined by flow cytometric Frizzled-4 surface expression.

shown in Fig. 4A. Real-time RT-PCR analyses verified high expression of Frizzled-4 in primitive hematopoietic progenitor cells (lin-). Fig. 4B shows the Frizzled-4 distribution in different FAB classes. Interestingly, Frizzled-4 expression was lower in FAB classes M1-M3 and increased in monocytic and erythroid leukemia development (FAB M4-M6).

Frizzled-4 overexpression in murine $32 \mathrm{D}$ cells and response to Wnt $3 a$. In order to understand the biological consequences of high Frizzled-4 expression we established stable cell lines overexpressing Frizzled-4 (Fig. 5A and B). Frizzled-4 surface expression was verified by flow cytometry in transfected cells whereas Frizzled-4 was undetectable in 32D wild-type cells. Growth of the murine myeloid progenitor cell line 32Dcl3 depends on the presence of IL-3. Expression of Flt3WT in these cells allows IL-3 to be substituted by FL $(18,25)$. To analyze the effects of the presence of Frizzled-4 receptor on the mediation of canonical Wnt-signaling, 32DFlt3WTPMY (control) or 32DFlt3WT/Frz-4 cells were incubated either in control medium or in Wnt3a containing medium. The cells were then assessed for $B$-catenin protein levels (Fig. 6A-C).

We observed a consistent increase in basal $ß$-catenin protein levels in both cell lines in comparison to non-stimulated cells (Fig. 6A). Stimulation of Frizzled-4 expressing cells with $\mathrm{Wnt} 3 \mathrm{a}$ revealed a more prominent increase of $B$-catenin protein level than the control cell line. These data suggest that the Frizzled-4 receptor mediates Wnt3a signalling via $\beta$ catenin stabilisation. To rule out non-specific induction of $\beta$ catenin protein levels we analyzed $\beta$-catenin induction in the presence of dkk-1, a potent inhibitor of Wnt ligands (26) (Fig. 6B). In the presence of Wnt3a conditioned medium, the addition of dkk-1 to the medium resulted in a reduction of B-catenin protein levels in both cell lines. These findings suggested a specific Wnt3a ligand, Frizzled-4 receptor interaction and induction of canonical Wnt-signalling. Next, we performed a competitive antibody assay to verify the specific interaction of Wnt3a with the Frizzled-4 receptor. An anti-Frizzled-4 antibody that interacts with the cysteinrich domain important for Wnt-binding was added to Wntcontaining medium. All the experiments were carried out with a control lacking Frizzled-4 antibody. The presence of antiFrizzled-4 antibody reduced $\mathrm{Wnt} 3 \mathrm{a}$ initiated $B$-catenin induction (Fig. 6C). We conclude that Frizzled-4 is a receptor for Wnt3a and thus can induce canonical Wnt signalling via B-catenin induction in hematopoietic cells.

The findings described so far provided evidence that Frizzled-4 induce $B$-catenin stabilization and thus sensitized cells for Wnt3a stimulation. We wondered whether this activation could result into any biological advantage for hematopoietic progenitor cells expressing Frizzled-4. Therefore, we studied the consequences of Wnt3a exposure on apoptosis of 32DFlt3WT/PMY or 32DFlt3WT/Frz4 cells. The cells were either incubated with control conditioned medium or Wnt3a conditioned medium and subsequently the apoptosis was assessed at indicated time points. Fig. 6D depicts the fold differences in viability of Wnt3a-treated cells of both cell lines in comparison to control conditioned medium for indicated time points. The fold viability in presence of Wnt3a compared with control conditioned was higher in Frizzled-4 expressing cells than in the control cell line. These data indicate that Frizzled-4-mediated canonical Wnt signalling results in a higher resistance against apoptosis. 
A

32DFlt3WT/PMY 32DFIt3WT/Frz-4

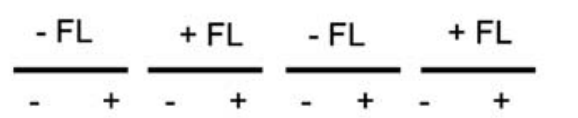

Wnt3a

beta-Catenin

D

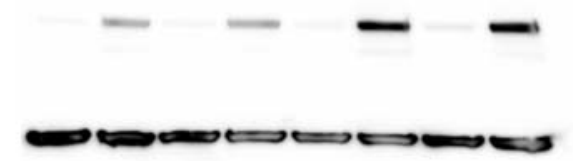

actin

B

\section{DFlt3WT/PMY 32DFlt3WT/Frz-4}
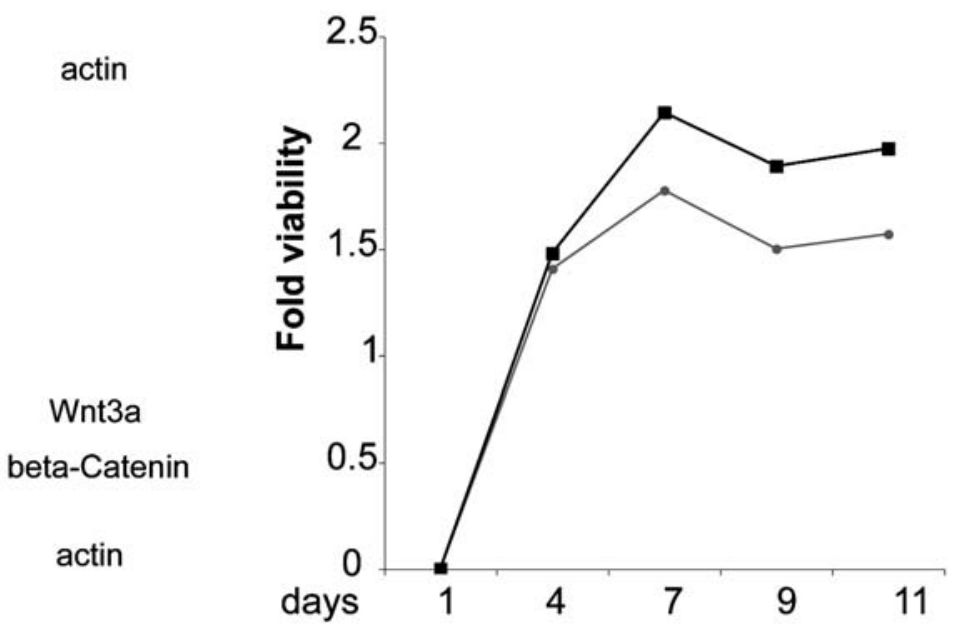

C

32DFIt3WT/PMY 32DFIt3WT/Frz-4

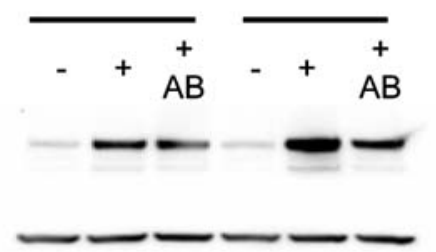

Wnt3a

beta-Catenin

actin

Figure 6. (A and B) 32D cells retrovirally transduced either with Frizzled-4 or empty vector were grown for $12 \mathrm{~h}$ in the absence of IL3. Subsequently, cells were stimulated with control or Wnt3a conditioned medium (50\%) in the presence or absence of FL or dkk-1, a specific Wnt inhibitor, for $6 \mathrm{~h}$. Western blot analyses were performed with the indicated primary antibody. (C) Cells were starved overnight before addition of control or Wnt3a conditioned medium $(25 \%)$ for 6 hours either in the presence or absence of neutralizing Frizzled-4 antibody (+AB). B-catenin Western blots verify the competition between Wnt ligand and antibody. (D) 32D cells retrovirally transduced either with Frizzled-4 or empty vector were kept in 50\% conditioned media. At the indicated time point dead cells were identified by propidium-iodide staining. The fold viability, showing the ratio of Wnt $3 \mathrm{a} /$ control conditioned medium of each construct, is represented for indicated time points. A representative experiment is shown out of 3.

\section{Discussion}

The evolutionary highly conserved Wnt signalling pathway has been described to be targeted by AML fusion proteins, serves important functions in hematopoiesis and stem cell self renewal and in Flt3-ITD-mediated transformation $(6,14,15,27)$. The mechanism of leukemic transformation and the role of Wnt signalling have not yet been completely analyzed. Prior to this study, we identified the Frizzled-4 receptor to be upregulated in Flt3-ITD over-expressing 32D cells (14).

In this study, we analyzed the expression of Frizzled-4 receptor on RNA and protein level in AML patients. Ectopic expression of Frizzled-4 in a cell line model revealed higher inducibility of $\beta$-catenin stabilisation when exposed to Wnt3a, which undergoes with higher apoptosis resistance. In addition, we demonstrated a specific Wnt3a-Frizzled-4 interaction, as Frizzled-4 was earlier described to interact with Wnt5a, a different class of Wnt ligands.
Wnt signalling regulates a variety of adult and developmental processes and misregulation of several components of the canonical Wnt signal transduction pathway results in tumorigenesis $(1,2)$. Two different classes of Wnt ligands have been described: 'Wnt3a' class, such as Wnt1 and Wnt3a, which is sufficient to induce a secondary dorsal-ventral axis in Xenopus embryos and morphologically transform mouse mammary epithelial cells, and the 'Wnt5a' a class that is not sufficient or acts even antagonistic to Wnts of the Wnt3a class $(28,29)$. The first association between a Wnt receptor and human disease was reported from Robitaille and colleagues (11), who found a function of Frizzled-4 in retinal angiogenesis. In their study, Frizzled-4 activated calcium/ calmodulin-dependent protein kinase II (CAMII), components of Wnt/calcium signalling pathway. In our studies, the expression of Frizzled-4 in the murine hematopoietic progenitor cell line and the exposure to Wnt3a was sufficient to induce B-catenin stability. The availability of Frizzled receptors have been discussed where a model propose that 
receptor context dictates Wnt signalling output (30). In addition, Mikels et al demonstrated, that Wnt5a can also activate $\beta$-catenin signalling in the presence of the appropriate Frizzled receptor, Frizzled-4. Furthermore, another study showed that vascular development in the retina and inner ear is controlled by Norrin and Frizzled-4, a high-affinity ligandreceptor pair (10). Based on these studies it is tempting to speculate that regulation of Wnt signalling can also be regulated by receptor availability besides Wnt proteins themselves.

There are several indices described that argue for a role of Wnt-signalling in hematopoietic stem cell self renewal and differentiation (6,31-33). In addition, Zhong and colleagues reported on a gene expression profile of murine long-term reconstituting verses short-term reconstituting hematopoietic stem cells (34). They identified 52 genes that had expression patterns that correlated positively with LTR HSC activity. These included two well characterized stem cell membrane protein genes c-Kit and the thrombopoetin receptor $\mathrm{cMpl}$. Interestingly, another potential stem cell related membrane protein identified was Frizzled-4. Therefore, Frizzled-4 is a good candidate to play a role in stem cell activity.

In conclusion, we demonstrated Frizzled-4 receptor to be increased in AML verses normal bone marrow and that the expression of Frizzled-4 in a murine hematopoietic progenitor cell line was sufficient to induce higher $\beta$-catenin levels in the presence of $\mathrm{Wnt} 3 \mathrm{a}$. Our results indicate a role for Frizzled-4 in directing canonical Wnt signalling pathway that itself is important in regulating hematopoiesis and in the pathogenesis of AML. Based on our studies it is possible that receptor availability is a major factor in hematopoietic cells and is important in the pathogenesis of AML.

\section{Acknowledgements}

We are grateful to Marion Baas for excellent technical assistance. We also thank Anand Reddi for providing the Dkk-1 expressing cell line and Dr Cati Logan and Dr Calvin Kuo for providing purified Dkk-1. We thank Dr Roel Nusse for the pCDNA.3-Frizzled-4 construct. We acknowledge Dr S. Corbacioglu for providing cKit-WT and cKit-ITD expression plasmid constructs (35). This work is supported by grants from the Deutsche Forschungsgemeinschaft (SFB293, Se 600/3-1), the José-Carreras Leukemia Foundation (R06/39f), the Innovative Medizinische Forschung (IMF Project No. TI 110506) and the Interdisciplinary Centre of Clinical Research Münster (IZKF Project No. Ser2/038/06; Mül 2/018/07).

\section{References}

1. Logan CY and Nusse R: The Wnt signaling pathway in development and disease. Annu Rev Cell Dev Biol 20: 781-810, 2004.

2. Polakis P: Wnt signaling and cancer. Genes Dev 14: 1837-1851, 2000.

3. Bhanot P, Brink M, Samos CH, Hsieh JC, Wang Y, Macke JP, Andrew D, Nathans J and Nusse R: A new member of the frizzled family from Drosophila functions as a Wingless receptor. Nature 382: 225-230, 1996.

4. Tamai K, Semenov M, Kato Y, Spokony R, Liu C, Katsuyama Y, Hess F, Saint-Jeannet JP and He X: LDL-receptor-related proteins in Wnt signal transduction. Nature 407: 530-535, 2000 .
5. Behrens J, von Kries JP, Kuhl M, Bruhn L, Wedlich D, Grosschedl R and Birchmeier W: Functional interaction of beta-catenin with the transcription factor LEF-1. Nature 382: 638-642, 1996.

6. Reya T, Duncan AW, Ailles L, Domen J, Scherer DC, Willert K, Hintz L, Nusse R and Weissman IL: A role for Wnt signalling in self-renewal of haematopoietic stem cells. Nature 423: 409-414, 2003.

7. Cobas M, Wilson A, Ernst B, Mancini SJ, MacDonald HR, Kemler R and Radtke F: Beta-catenin is dispensable for hematopoiesis and lymphopoiesis. J Exp Med 199: 221-229, 2004.

8. Scheller M, Huelsken J, Rosenbauer F, Taketo MM, Birchmeier W, Tenen DG and Leutz A: Hematopoietic stem cell and multilineage defects generated by constitutive betacatenin activation. Nat Immunol 7: 1037-1047, 2006.

9. Kirstetter P, Anderson K, Porse BT, Jacobsen SE and Nerlov C: Activation of the canonical Wnt pathway leads to loss of hematopoietic stem cell repopulation and multilineage differentiation block. Nat Immunol 7: 1048-1056, 2006.

10. Xu Q, Wang Y, Dabdoub A, Smallwood PM, Williams J, Woods C, Kelley MW, Jiang L, Tasman W, Zhang K and Nathans J: Vascular development in the retina and inner ear: control by Norrin and Frizzled-4, a high-affinity ligand-receptor pair. Cell 116: 883-895, 2004.

11. Robitaille J, MacDonald ML, Kaykas A, Sheldahl LC, Zeisler J, Dube MP, Zhang LH, Singaraja RR, Guernsey DL, Zheng B, Siebert LF, Hoskin-Mott A, Trese MT, Pimstone SN, Shastry BS, Moon RT, Hayden MR, Goldberg YP and Samuels ME: Mutant frizzled-4 disrupts retinal angiogenesis in familial exudative vitreoretinopathy. Nat Genet 32: 326-330, 2002.

12. Kaykas A, Yang-Snyder J, Heroux M, Shah KV, Bouvier M and Moon RT: Mutant Frizzled 4 associated with vitreoretinopathy traps wild-type Frizzled in the endoplasmic reticulum by oligomerization. Nat Cell Biol 6: 52-58, 2004.

13. Gregorieff A, Pinto D, Begthel H, Destree O, Kielman M and Clevers H: Expression pattern of Wnt signaling components in the adult intestine. Gastroenterology 129: 626-638, 2005.

14. Tickenbrock L, Schwable J, Wiedehage M, Steffen B, Sargin B, Choudhary C, Brandts C, Berdel WE, Muller-Tidow C and Serve H: Flt3 tandem duplication mutations cooperate with Wnt signaling in leukemic signal transduction. Blood 105: 3699$3706,2005$.

15. Muller-Tidow C, Steffen B, Cauvet T, Tickenbrock L, Ji P, Diederichs S, Sargin B, Kohler G, Stelljes M, Puccetti E, Ruthardt M, deVos S, Hiebert SW, Koeffler HP, Berdel WE and Serve H: Translocation products in acute myeloid leukemia activate the Wnt signaling pathway in hematopoietic cells. Mol Cell Biol 24: 2890-2904, 2004.

16. Buhring HJ, Sures I, Jallal B, Weiss FU, Busch FW, Ludwig WD, Handgretinger R, Waller HD and Ullrich A: The receptor tyrosine kinase p185HER2 is expressed on a subset of B-lymphoid blasts from patients with acute lymphoblastic leukemia and chronic myelogenous leukemia. Blood 86: 1916-1923, 1995.

17. Buchner T, Hiddemann W, Wormann B, Loffler H, Gassmann W, Haferlach T, Fonatsch C, Haase D, Schoch C, Hossfeld D, Lengfelder E, Aul C, Heyll A, Maschmeyer G, Ludwig WD, Sauerland MC and Heinecke A: Double induction strategy for acute myeloid leukemia: the effect of high-dose cytarabine with mitoxantrone instead of standard-dose cytarabine with daunorubicin and 6-thioguanine: a randomized trial by the German AML Cooperative Group. Blood 93: 4116-4124, 1999.

18. Mizuki M, Fenski R, Halfter H, Matsumura I, Schmidt R, Muller C, Gruning W, Kratz-Albers K, Serve S, Steur C, Buchner T, Kienast J, Kanakura Y, Berdel WE and Serve H: Flt3 mutations from patients with acute myeloid leukemia induce transformation of 32D cells mediated by the Ras and STAT5 pathways. Blood 96: 3907-3914, 2000.

19. Mizuki M, Schwable J, Steur C, Choudhary C, Agrawal S, Sargin B, Steffen B, Matsumura I, Kanakura Y, Bohmer FD, Muller-Tidow C, Berdel WE and Serve H: Suppression of myeloid transcription factors and induction of STAT response genes by AML-specific Flt3 mutations. Blood 101: 3164-3173, 2003.

20. Choudhary C, Brandts C, Schwable J, Tickenbrock L, Sargin B, Ueker A, Bohmer FD, Berdel WE, Muller-Tidow C and Serve H: Activation mechanisms of STAT5 by oncogenic Flt3-ITD. Blood 110: 370-374, 2007. 
21. Kuhnert F, Davis CR, Wang HT, Chu P, Lee M, Yuan J, Nusse R and Kuo CJ: Essential requirement for Wnt signaling in proliferation of adult small intestine and colon revealed by adenoviral expression of Dickkopf-1. Proc Natl Acad Sci USA 101: 266-271, 2004.

22. Muller C, Readhead C, Diederichs S, Idos G, Yang R, Tidow N, Serve H, Berdel WE and Koeffler HP: Methylation of the cyclin A1 promoter correlates with gene silencing in somatic cell lines, while tissue-specific expression of cyclin A1 is methylation independent. Mol Cell Biol 20: 3316-3329, 2000.

23. Worch J, Tickenbrock L, Schwable J, Steffen B, Cauvet T, Mlody B, Buerger H, Koeffler HP, Berdel WE, Serve H and Muller-Tidow C: The serine-threonine kinase MNK1 is posttranslationally stabilized by PML-RARalpha and regulates differentiation of hematopoietic cells. Oncogene 23: 9162-9172, 2004.

24. Wang Y, Barbacioru C, Hyland F, Xiao W, Hunkapiller KL, Blake J, Chan F, Gonzalez C, Zhang L and Samaha RR: Large scale real-time PCR validation on gene expression measurements from two commercial long-oligonucleotide microarrays. BMC Genomics 7: 59, 2006.

25. Fenski R, Flesch K, Serve S, Mizuki M, Oelmann E, KratzAlbers K, Kienast J, Leo R, Schwartz S, Berdel WE and Serve H: Constitutive activation of FLT3 in acute myeloid leukaemia and its consequences for growth of 32D cells. Br J Haematol 108: 322-330, 2000

26. Semenov MV, Tamai K, Brott BK, Kuhl M, Sokol S and He X: Head inducer Dickkopf-1 is a ligand for Wnt coreceptor LRP6. Curr Biol 11: 951-961, 2001.

27. Reya T: Regulation of hematopoietic stem cell self-renewal. Recent Prog Horm Res 58: 283-295, 2003.
28. Du SJ, Purcell SM, Christian JL, McGrew LL and Moon RT: Identification of distinct classes and functional domains of Wnts through expression of wild-type and chimeric proteins in Xenopus embryos. Mol Cell Biol 15: 2625-2634, 1995.

29. Wong GT, Gavin BJ and McMahon AP: Differential transformation of mammary epithelial cells by Wnt genes. Mol Cell Biol 14: 6278-6286, 1994.

30. Mikels AJ and Nusse R: Purified Wnt5a protein activates or inhibits beta-catenin-TCF signaling depending on receptor context. PLoS Biol 4: e115, 2006.

31. Willert K, Brown JD, Danenberg E, Duncan AW, Weissman IL, Reya T, Yates JR III and Nusse R: Wnt proteins are lipidmodified and can act as stem cell growth factors. Nature 423 448-452, 2003.

32. Brandon C, Eisenberg LM and Eisenberg CA: WNT signaling modulates the diversification of hematopoietic cells. Blood 96 4132-4141, 2000.

33. Austin TW, Solar GP, Ziegler FC, Liem L and Matthews W: A role for the Wnt gene family in hematopoiesis: expansion of multilineage progenitor cells. Blood 89: 3624-3635, 1997.

34. Zhong JF, Zhao Y, Sutton S, Su A, Zhan Y, Zhu L, Yan C, Gallaher T, Johnston PB, Anderson WF and Cooke MP: Gene expression profile of murine long-term reconstituting vs. shortterm reconstituting hematopoietic stem cells. Proc Natl Acad Sci USA 102: 2448-2453, 2005.

35. Corbacioglu S, Kilic M, Westhoff MA, Reinhardt D, Fulda S and Debatin KM: Newly identified c-KIT receptor tyrosine kinase ITD in childhood AML induces ligand-independent growth and is responsive to a synergistic effect of imatinib and rapamycin. Blood 108: 3504-3513, 2006. 